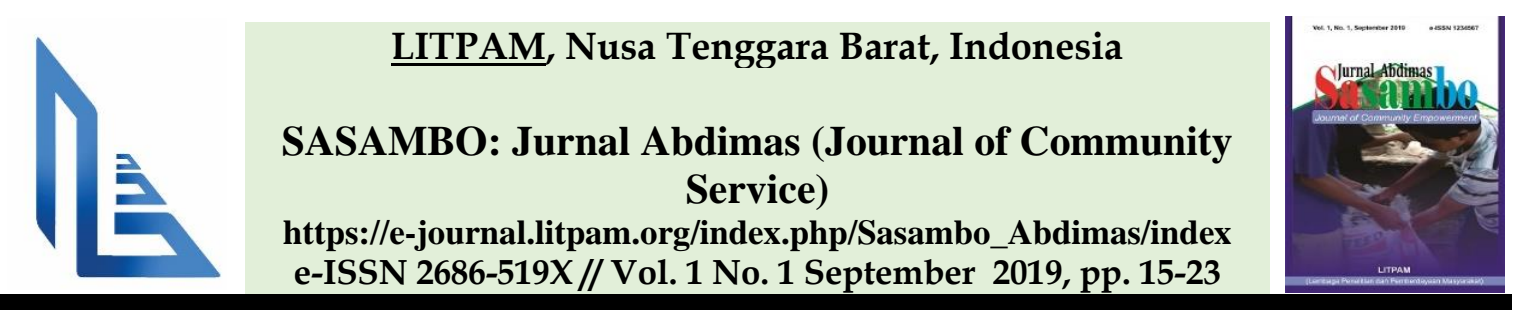

\title{
Pemberdayaan Masyarakat Melalui Chemistry Enterpreneurship di Desa Gondang Kabupaten Lombok Utara
}

\author{
${ }^{1}$ Ratna Azizah Mashami, ${ }^{2}$ Menik Aryani, ${ }^{3}$ Ahmadi \\ ${ }^{1 \& 3}$ Prodi Pendidikan Kimia, FPMIPA, IKIP Mataram, Jl. Pemuda No. 59A, Mataram, \\ Indonesia 83125 \\ ${ }^{2}$ Prodi Administrasi Pendidikan, FIP, IKIP Mataram, J1. Pemuda No. 59A, Mataram, Indonesia \\ 83125
}

Email Korespondensi: ratnamashami@ikipmataram.ac.id

\begin{tabular}{|c|c|}
\hline Article Info & bstract \\
\hline $\begin{array}{l}\text { Received: 02-09-2019 } \\
\text { Revised: 26-09-2019 } \\
\text { Published: 30-09-2019 }\end{array}$ & \multirow[b]{2}{*}{$\begin{array}{l}\text { Gondang Village is one of the villages that was badly damaged by the earthquake } \\
\text { a year ago. In addition to swallowing fatalities, the earthquake also resulted in } \\
\text { badly damaged houses and public facilities. Employers lose their business, so } \\
\text { too workers lose their jobs. To start a new business, the victims did not have the } \\
\text { capital and did not know what kind of business they would pursue. This service } \\
\text { aims to provide skills to the community through chemistry entrepreneurship so } \\
\text { that people can start entrepreneurship. Chemistry entrepreneurship involves the } \\
\text { process of converting innovations from chemicals into products that can be } \\
\text { marketed for commercial gain. The products to be made this time are a liquid } \\
\text { detergent, dish soap, softener, and sof trika. These four products are basic needs } \\
\text { in the household so this business opportunity is very promising. The KKN PPM } \\
\text { program was held for } 1 \text { month. There were 93 people involved in this activity } \\
\text { representing } 11 \text { hamlets. The stages of the KKN PPM activities are preparation, } \\
\text { trial, production, and marketing review. All of these activities involved } 20 \\
\text { students who worked with the community. The people of Gondang Village have } \\
\text { received training in making liquid detergent, dish soap, softener, and } \\
\text { hydrophobic along with a sales strategy. Product sales have increased in number } \\
\text { based on the first and second evaluations. Community income also increased. } \\
\text { The resulting product has been officially launched as a superior product in } \\
\text { Gondang Village. The service team and students have successfully carried out } \\
\text { community empowerment through chemistry entrepreneurship. }\end{array}$} \\
\hline $\begin{array}{l}\text { Keywords } \\
\text { community empowerme } \\
\text { chemistry } \\
\text { entrepreneurship }\end{array}$ & \\
\hline Inf & \\
\hline $\begin{array}{l}\text { Sejaral } \\
\text { Diterim } \\
\text { Direvis } \\
\text { Dipubli }\end{array}$ & \multirow{2}{*}{$\begin{array}{l}\text { Desa Gondang adalah salah satu desa yang mengalami rusak berat akibat } \\
\text { bencana gempa bumi setahun yang lalu. Selain menelan korban jiwa, gempa juga } \\
\text { mengakibatkan rumah dan fasilitas umum rusak parah. Para pengusaha } \\
\text { kehilangan usahanya, demikian pula dengan para pekerja kehilangan } \\
\text { pekerjaannya. Untuk memulai usaha baru, para korban tidak memiliki modal dan } \\
\text { tidak tahu jenis usaha apa yang akan ditekuni. Pengabdian ini bertujuan untuk } \\
\text { memberikan keterampilan kepada masyarakat melalui chemistry } \\
\text { entrepreneurship sehingga masyarakat bisa mulai berwirausaha. Chemistry } \\
\text { enterpreneurship melibatkan proses konversi inovasi dari kimia menjadi produk } \\
\text { yang dapat dipasarkan untuk keuntungan komersial. Produk yang akan dibuat } \\
\text { kali ini adalah deterjen cair, sabun cuci piring, softener, dan softrika. Keempat } \\
\text { produk tersebut adalah kebutuhan pokok dalam rumah tangga sehingga peluang } \\
\text { usaha ini sangat menjanjikan. Kegiatan KKN PPM ini dilaksanakan selama } 1 \\
\text { bulan. Masyarakat yang terlibat pada kegiatan ini berjumlah } 93 \text { orang yang } \\
\text { mewakili } 11 \text { dusun. Adapun tahapan kegiatan KKN PPM adalah persiapan, }\end{array}$} \\
\hline & \\
\hline
\end{tabular}


percobaan, produksi, dan marketing review. Seluruh kegiatan tersebut melibatkan 20 orang mahasiswa yang bekerja bersama masyarakat. Masyarakat Desa Gondang telah mendapatkan pelatihan pembuatan deterjen cair, sabun cuci piring, softener, dan softrika disertai strategi penjualan. Penjualan produk mengalami peningkatan jumlah berdasarkan evaluasi pertama dan kedua. Pendapatan masyarakat pun meningkat. Produk yang dihasilkan telah resmi dilaunching sebagai produk unggulan Desa Gondang. Tim pengabdian dan mahasiswa telah berhasil melaksanakan pemberdayaan masyarakat melalui chemistry entrepreneurship.

Sitasi: Mashami, R., A., Aryani, M., \& Ahmadi (2019) Pemberdayaan Masyarakat Melalui Chemistry Enterpreneurship di Desa Gondang Kabupaten Lombok Utara. Sasambo: Jurnal Abdimas (Journal of Community Service), 1(1), 15-23. doi: https://doi.org/10.36312/sasambo.v1i1.116

\section{PENDAHULUAN}

Gempa tektonik melanda Pulau Lombok pada tanggal 29 Juli 2019 dengan kekuatan 6,4 SR. Sepekan kemudian, 5 Agustus 2018, gempa bumi yang lebih kuat sebesar 7 SR terjadi lagi dan berpusat di Kabupaten Lombok Utara. Beberapa pekan kemudian gempa juga melanda Pulau Sumbawa. Sejak saat itu di provinsi NTB telah terjadi ribuan kali gempa susulan dan beberapa di antaranya bahkan dengan kekuatan cukup besar. Dampak yang ditimbulkan dari terjadinya suatu bencana alam sangatlah besar, mengingat hal ini bersifat multiplikatif (Cavallo et al., 2011). Dampak gempa bumi dibagi menjadi dampak langsung dan tidak langsung. Kerugian langsung akibat bencana menjadi fokus dari banyak upaya mitigasi dan kesiapsiagaan sebagai kunci mengurangi dampak langsung. Apabila kerugian langsung dapat segera diatasi, maka dampak sekundernya dapat dikurangi atau dicegah. Kerugian ekonomi yang secara langsung teramati adalah kerugian rusak dan hancurnya perumahan dan sektor usaha tidak hanya berakibat pada kerugian output yang tidak bisa dihasilkan, tetapi juga kemungkinan munculnya kemiskinan sebagai akibat dari penyesuaian kondisi struktural masyarakat yang berubah. Sedangkan dampak tidak langsung dapat terus terjadi dari waktu ke waktu, karena itu diperlukan untuk membandingkan situasi yang berkembang setelah bencana dengan situasi yang terjadi tanpa bencana. Tingkat gangguan ekonomi yang disebabkan oleh bencana sangat dipengaruhi oleh derajat gangguan yang dapat menyebar melalui jaringan ekonomi (Artiani, 2011).

Bagi Kabupaten Lombok Utara, gempa bumi tersebut sangat mempengaruhi perekonomian daerah. Menteri Perencanaan Pembangunan Nasional/Kepala Bappenas, Bambang Brodjonegoro, mengakui bahwa musibah tersebut diperkirakan bakal berdampak cukup signifikan bagi perekonomian wilayah setempat, bahkan diperkirakan hanya mengalami pertumbuhan sekitar nol persen lantaran terkena imbas dari musibah gempa bumi (Sutarno, 2018). Perkiraan ini sepertinya benar akan terjadi karena melihat kondisi masyarakat pascagempa yang kehilangan tempat tinggal serta fasilitas umum yang selama ini menopang usaha mereka.

Kabupaten Lombok Utara memiliki topografi pegunungan dan pantai sehingga mata pencaharian masyarakat beragam. Sektor pariwisata daerah ini juga sangat terkenal dengan tiga gili nya dan air terjun yang viral akhir-akhir ini. Desa Gondang salah satu dari 33 desa di Kabupaten Lombok Utara. Desa Gondang merupakan wilayah dengan luas sebesar $29,20 \mathrm{~km}^{2}$. Kondisi alam di desa ini masih didominasi oleh tanah kering dan hanya sebagian kecil saja yang menjadi areal persawahan. Gondang berbatasan langsung dengan Laut Jawa di sebelah Utaranya. Penduduk desa Gondang bekerja di bidang pertanian, industri, perdagangan, nelayan, penyedia jasa, dan sisanya ibu rumah tangga (Utara, 2017). Setelah gempa bumi melanda, semua aktivitas masyarakat tersebut lumpuh. Bagi pedagang dan ibu rumah tangga yang mempunyai usaha rumahan, memulai kembali usaha sangatlah sulit. Modal usaha tidak ada, kalaupun ada jumlahnya sedikit. Saat ini mereka fokus pada memperbaiki rumah, kalaupun ada uang akan digunakan untuk membangun rumah. 
Hal yang tidak kalah pentingnya adalah semangat berwirausaha masyarakat harus terus didorong. Pada tahap rekonstruksi, pemerintah membangun kembali semua prasarana dan sarana, kelembagaan pada wilayah pascabencana, baik pada tingkat pemerintahan maupun masyarakat dengan sasaran utama tumbuh dan berkembangnya kegiatan perekonomian, sosial dan budaya, tegaknya hukum dan ketertiban, dan bangkitnya peran serta masyarakat dalam segala aspek kehidupan bermasyarakat pada wilayah pascabencana (Fillah et al., 2010). Peran serta masyarakat dalam mengembangkan perekonomian daerah sangat diperlukan. Namun, dengan kondisi saat ini masyarakat kebingungan memulai usahanya dari mana dan seperti apa. IKIP Mataram sebagai salah satu Perguruan Tinggi yang mewajibkan matakuliah KKN dapat berkontribusi dengan mengirimkan mahasiswa untuk ikut terlibat menjalankan program pemberdayaan masyarakat. Program tersebut dikhususkan pada membantu masyarakat memulai usaha yang dapat meningkatkan perekonomian mereka.

Untuk mencapai tujuan tersebut, tim bermitra dengan Pemerintah Desa Gondang. Desa Gondang merupakan salah satu desa terbaik di Kabupaten Lombok Utara maupun di NTB. Lebih khusus lagi karena Desa Gondang telah menggunakan aplikasi Siskeudes (Sistem Keuangan Desa) dalam penyusunan laporan Dana Desa. Sarana perekonomian di Desa Gondang antara lain 1 pasar umum, 96 toko/kios, 16 warung, dan 1 KUD. Jumlah penduduk desa Gondang cukup besar dengan kepadatan 305 jiwa/km2. Banyaknya penduduk bisa menjadi potensi yang dapat dimanfaatkan sebaik-baiknya demi kesejahteraan penduduk tersebut. Pemerintah Desa Gondang sangat mendukung dan bersedia bekerja bersama mahasiswa dalam kegiatan KKN PPM. Oleh karena itu, mitra memberikan bantuan dana inkind berupa posko mahasiswa dan ruangan pelatihan. Tidak banyak yang bisa pemerintah Desa Gondang berikan sebagai dana bantuan karena kondisi mereka yang juga dalam masa rekontruksi. Setelah kegiatan KKN PPM berakhir, diharapkan perekonomian masyarakat membaik ditandai dengan pendapatan yang meningkat. Disamping itu kedepannya masyarakat tetap bisa menekuni usaha ini dan menjadikannya sebagai lapangan usaha.

Berdasarkan masalah yang dipaparkan sebelumnya, tim pengusul ingin membantu masyarakat Desa Gondang menciptakan peluang usaha melalui chemistry enterpreneurship. Chemistry atau kimia ada dimana saja di sekitar kita. Tidak ada hari tanpa kimia dan tidak ada kegiatan tanpa kimia. Sebagai timbal baliknya kimia menawarkan berbagai peluang wirausaha (enterpreneurship) yang luas untuk pengembangan usaha kecil dan menengah daripada disiplin ilmu lainnya. Ahli kimia profesional termasuk mahasiswa kimia maupun masyarakat umum, dengan sedikit pelatihan keterampilan kewirausahaan dapat mulai mengomersilkan inovasi mereka untuk mendapatkan keuntungan finansial yang sangat besar, menjadi pencipta pekerjaan dan berkontribusi positif terhadap pembangunan ekonomi daerah terutama melalui usaha kecil dan menengah.

Chemistry enterpreneurship melibatkan proses konversi inovasi dari kimia menjadi produk yang dapat dipasarkan untuk keuntungan komersial (Oyeku et al., 2015). Produk yang akan dibuat kali ini adalah deterjen cair, dishwash (sabun cuci piring), softener, dan softrika. Keempat produk tersebut adalah kebutuhan pokok dalam rumah tangga sehingga bisa dipastikan pasaran produk sangat luas. Belum lagi ditambah dengan kebutuhan hotel jika pariwisata Lombok Utara telah pulih. Jika dibandingkan dengan produk serupa yang dijual di swalayan, produk chemistry enterpreneurship ini memiliki kualitas yang sama tetapi dengan biaya produksi kurang dari 50\% harga jual. Jadi keuntungan yang bisa didapatkan sangat besar. Kegiatan KKN PPM ini tidak hanya membuat produk, tetapi juga memberikan edukasi kepada masyarakat tentang pemasaran atau marketing. Marketing adalah ujung tombak bagi sebuah usaha. Tanpa marketing maka pertumbuhan usaha akan sangat lambat bahkan bisa jadi akan hilang dari peredaran persaingan usaha karena semakin hari semakin banyak bermunculan usaha baru. Ada banyak strategi yang bisa digunakan untuk mengembangkan sebuah bisnis, salah satunya adalah marketing mix. Marketing mix terdiri dari 7 unsur, yaitu Product, Price, Promotion, Place, Participant, Process, dan Physical Evidence yang disingkat 7P. Setelah 
program berakhir, masyarakat diharapkan dapat melanjutkan usaha ini dan mengembangkannya di masing-masing dusun sehingga terbentuk unit usaha yang lebih banyak. Tim menargetkan akan terbentuk minimal lima unit usaha kecil di Desa Gondang.

\section{METODE}

Program KKN PPM ini dilaksanakan selama satu bulan sesuai dengan alokasi waktu kegiatan KKN di IKIP Mataram. Peserta kegiatan adalah masyarakat desa gondang berjumlah 55 orang yang mewakili 11 dusun. Adapun tahapan pelaksanaan KKN PPM terdiri dari enam tahap, yaitu persiapan, pembekalan, pengenalan, percobaan, produksi, dan marketing review (Gambar 1).

\section{Persiapan}

Pada tahap awal dilakukan penjaringan mahasiswa peserta KKN PPM. Mahasiswa mendaftar melalui program studi masing-masing dan melengkapi berkas-berkas yang dibutuhkan. Mahasiswa yang memenuhi syarat akan dinyatakan lulus dan berhak mengikuti kegiatan.

2. Pembekalan

Mahasiswa yang berjumlah 20 orang mengikuti pembekalan pada pekan pertama. Materi yang diberikan saat pembekalan adalah pemberdayaan masyarakat, etika di masyarakat, kewirausahaan dan strategi pemasaran, pengenalan alat dan bahan laboratorium sederhana, proses produksi deterjen cair, dishwash (sabun cuci piring), softener, dan softrika,

3. Pengenalan

Pada tahap ini tim akan memperkenalkan alat dan bahan yang diperlukan setiap produk, cara menggunakan alat, sifat kimia bahan dan cara menanganinya, cara membuat produk. Selain itu, tim akan menjelaskan strategi marketing. Tahap ini berlangsung pada pekan kedua.

4. Percobaan

Pada pekan ketiga, tim akan memperagakan cara membuat produk. Peserta dibagi ke dalam 5 kelompok dan setiap kelompok didampingi oleh 4 mahasiswa. Setiap kelompok juga mencoba membuat produk lalu bersama-sama menganalisis biaya yang dikeluarkan sehingga bisa merencanakan harga jual. Pada tahap ini peserta dibantu mahasiswa mempersiapkan kemasan dan labelnya.

5. Produksi

Pada pekan keempat dan seterusnya dilakukan proses produksi deterjen cair, sabun cuci piring, softener, dan softrika. Kemudian dilanjutkan dengan pengemasan, promosi, dan penjualan. Promosi dilakukan dengan penyebaran brosur dan beriklan di media sosial. Penjualan secara langsung dengan menitipkan di warung atau toko dan berjualan di pasar.

6. Marketing review

Setelah dipasarkan selama 7 hari sekali selama 2 pekan, tim melakukan marketing review. Tim dan peserta mendiskusikan bagaimana proses penjualan lalu mengevaluasi apa kelebihan yang harus dipertahankan dan kekurangan yang harus segera diperbaiki pada penjualan berikutnya.

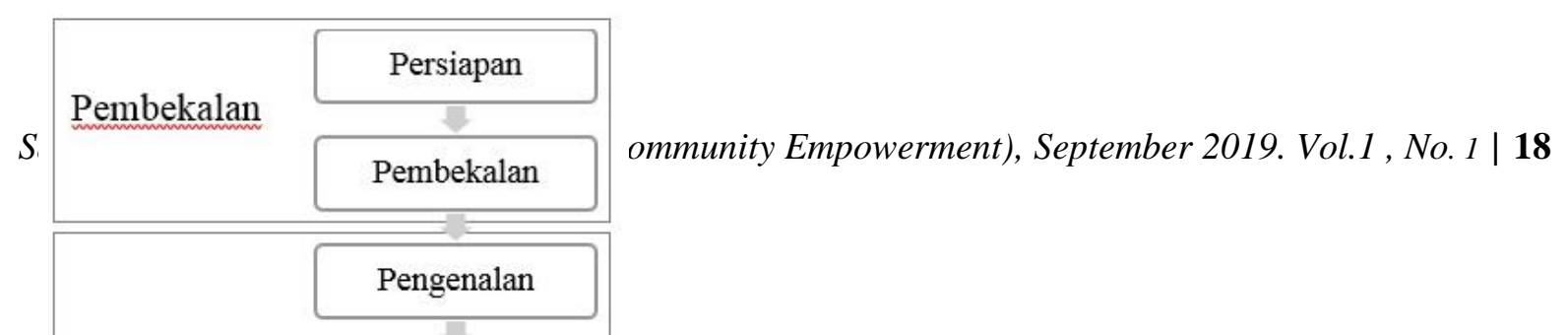




\section{Gambar 1. Diagram Alir Program KKN PPM}

Adapun volume pekerjaan mahasiswa sebanyak 158 JKEM untuk setiap mahasiswa. Rincian volume total pekerjaan sebanyak 3.160 JKEM untuk 20 orang mahasiswa dapat dilihat pada Tabel 1 .

Tabel 1. Uraian Jam Kerja Efektif Mahasiswa

\begin{tabular}{|c|c|c|c|}
\hline No. & Program & Kegiatan & Volume JKEM \\
\hline \multirow[t]{7}{*}{1} & \multirow{7}{*}{$\begin{array}{l}\text { Pengenalan atau } \\
\text { sosialisasi } \\
\text { chemistry } \\
\text { enterpreneurship }\end{array}$} & Studi pustaka & 6 jam $\times 5$ orang $=30$ \\
\hline & & Pembuatan buku panduan & 10 jam $\times 8$ orang $=80$ \\
\hline & & Penyusunan materi sosialisasi & 5 jam $x 4$ orang $=20$ \\
\hline & & $\begin{array}{l}\text { Penyiapan dan pengadaan alat dan } \\
\text { bahan yang akan dikenalkan }\end{array}$ & 10 jam $\times 5$ orang $=50$ \\
\hline & & Penyiapan tempat sosialisasi & 2 jam $\times 5$ orang $=10$ \\
\hline & & Melakukan sosialisasi & 10 jam $\times 5$ orang $=50$ \\
\hline & & Dokumentasi & 10 jam $\times 2$ orang $=20$ \\
\hline \multirow[t]{8}{*}{2} & \multirow{8}{*}{$\begin{array}{l}\text { Percobaan } \\
\text { pembuatan } \\
\text { produk } \\
\text { chemistry } \\
\text { enterpreneurship }\end{array}$} & Persiapan alat dan bahan & 2 jam $\times 5$ orang $=10$ \\
\hline & & Persiapan ruangan & 1 jam $\times 5$ orang $=5$ \\
\hline & & Demonstrasi membuat produk & 16 jam $\times 10$ orang $=160$ \\
\hline & & Pendampingan kelompok & 16 jam $\times 10$ orang $=160$ \\
\hline & & Analisis harga & 10 jam $\times 10$ orang $=100$ \\
\hline & & Pembuatan dan desain label & 10 jam $\times 5$ orang $=50$ \\
\hline & & Pengadaan kemasan & 10 jam $\times 5$ orang $=50$ \\
\hline & & Dokumentasi & 10 jam $\times 2$ orang $=20$ \\
\hline \multirow[t]{13}{*}{3} & \multirow{13}{*}{$\begin{array}{l}\text { Produksi } \\
\text { deterjen cair, } \\
\text { dishwash (sabun } \\
\text { cuci piring), } \\
\text { softener, dan } \\
\text { softrika, }\end{array}$} & Persiapan alat dan bahan & 10 jam $\times 5$ orang $=10$ \\
\hline & & Pengadaan bahan & 10 jam $\times 5$ orang $=10$ \\
\hline & & Persiapan ruangan & 6 jam $\times 5$ orang $=30$ \\
\hline & & Pembuatan produk selama 2 pekan & 50 jam $\times 10$ orang $=500$ \\
\hline & & Pendampingan kelompok & 40 jam $\times 10$ orang $=400$ \\
\hline & & Pengadaan kemasan & 20 jam $\times 5$ orang $=100$ \\
\hline & & Pengemasan produk & 40 jam $\times 10$ orang $=400$ \\
\hline & & Pembuatan brosur & 10 jam $\times 5$ orang $=50$ \\
\hline & & Penyebaran brosur & 20 jam $\times 10$ orang $=200$ \\
\hline & & Pembuatan iklan di media social & 20 jam $\times 2$ orang $=40$ \\
\hline & & Penjualan di warung/took & 20 jam $\times 5$ orang $=100$ \\
\hline & & Penjualan di pasar & 20 jam $\times 5$ orang $=100$ \\
\hline & & Pengantaran pesanan/produk & 20 jam $\times 4$ orang $=80$ \\
\hline
\end{tabular}




\begin{tabular}{lll} 
& Dokumentasi & 20 jam $\times 2$ orang $=40$ \\
review & Persiapan ruangan & 3 jam x 5 orang $=15$ \\
& $\begin{array}{l}\text { Pengumpulan data penjualan dalam } \\
\text { sepekan selama 2 pekan }\end{array}$ & 10 jam x 5 orang $=50$ \\
& $\begin{array}{l}\text { Analisis data penjualan } \\
\text { Diskusi kelompok }\end{array}$ & 20 jam x 5 orang $=100$ \\
& Dokumentasi & 20 jam x 5 orang $=100$ \\
& 10 jam $\times 2$ orang $=20$ \\
\hline
\end{tabular}

\section{HASIL DAN PEMBAHASAN}

Program KKN PPM telah dilaksanakan selama satu bulan penuh pada bulan Agustus sesuai dengan alokasi waktu kegiatan KKN di IKIP Mataram Tahun Akademik 2019/2010. Tujuan kegiatan ini adalah membantu masyarakat menjalankan sebuah usaha untuk meningkatkan kesejahteraannya. Peluang usaha yang diperkenalkan melalui kegiatan KKN PPM adalah pembuatan deterjen cair, sabun cuci piring, softener, dan softrika. Adapun hasil kegiatan pada setiap tahap sebagai berikut:

1. Persiapan

Langkah awal kegiatan ini adalah merekrut mahasiswa. Mekanisme pendaftaran telah ditentukan oleh LPPM sehingga tim pengabdian mengikuti alur yang sudah ditetapkan. Pada tahap awal ini terpilih 20 mahasiswa untuk mengikuti program KKN PPM. Mahasiswa terdiri dari delapan mahasiswa pendidikan olahraga, dua mahasiswa pendidikan kimia, satu mahasiswa pendidikan fisika, satu mahasiswa pendidikan matematika, satu mahasiswa pendidikan biologi, dua mahasiswa pendidikan bahasa inggris, dua mahasiswa teknologi pendidikan, satu mahasiswa administrasi pendidikan, satu mahasiswa pendidikan konseling, dan satu mahasiswa pendidikan luar sekolah.

2. Pembekalan

Mahasiswa telah mengikuti empat kali pembekalan. Pembekalan pertama mengenai penjelasan program KKN PPM, pemberdayaan masyarakat, etika bermasyarakat, kewirausahaan, dan strategi pemasaran yang diisi oleh LPPM IKIP Mataram dan narasumber ahli. Pembekalan kedua mengenai pembuatan deterjen cair dan sabun cuci piring. Pembekalan ketiga tentang pembuatan softener dan softrika. Pembekalan kedua diberikan oleh narasumber ahli dan tim pengabdian. Selain penjelasan sifat bahan, mahasiswa diajarkan praktik pembuatan produk. Pembekalan keempat dilakukan dengan mengunjungi industri rumahan pembuatan keempat produk tersebut dengan tujuan mahasiswa belajar proses pembuatan skala besar sampai proses pengemasan. Mahasiswa juga diajarkan menggunakan mesin pengaduk untuk proses produksi.
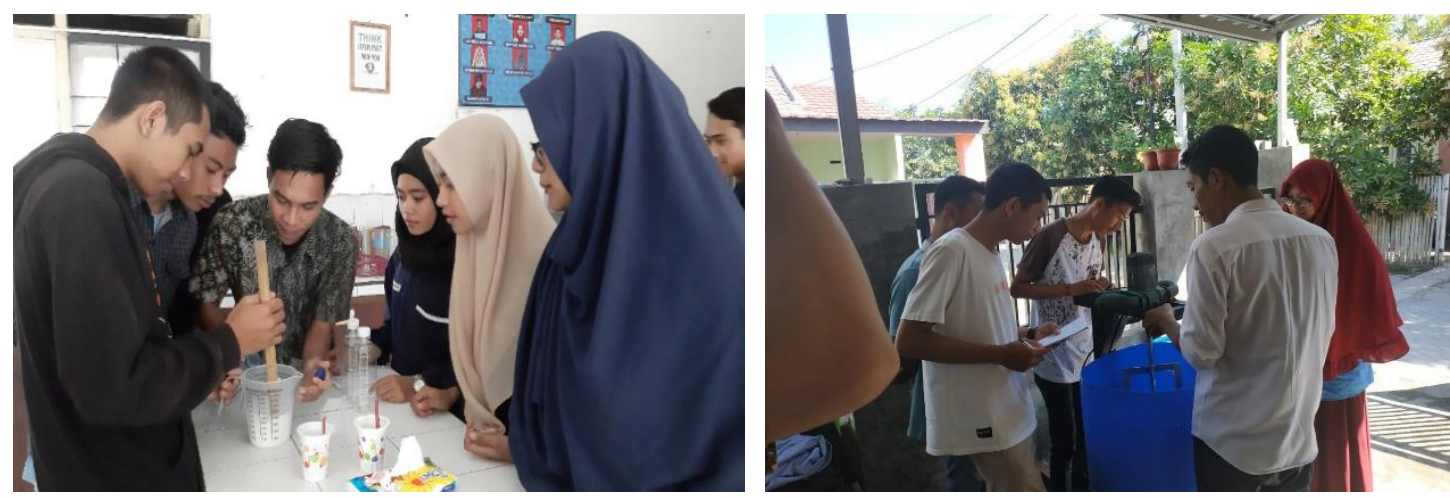

Gambar 2. Pembekalan Mahasiswa

3. Pengenalan 
Mahasiswa tiba di Desa Gondang dan diterima secara resmi oleh staf desa pada tanggal 31 Juli 2019. Pada pekan pertama, mahasiswa melakukan sosialisasi kepada masyarakat di seluruh dusun mengenai program kerja mereka dan membawa contoh produk yang dibuat. Tahap ini sekaligus digunakan mahasiswa untuk mengenal situasi dan latar belakang masyarakat.

4. Percobaan

Pada pekan kedua, tim melakukan pelatihan pembuatan produk. Kegiatan pelatihan diikuti oleh 50 orang yang merupakan perwakilan dari sebelas dusun, yaitu karang pendagi, karang anyar, bestari, lekok tenggara, lekok selatan, lekok utara, karang amor, karang kates, lekok timur, karang bedil, dan gondang timur. Kegiatan ini menghadirkan narasumber yang merupakan produsen keempat produk yang dilatih. Masyarakat melakukan praktik langsung membuat produk didampingi oleh mahasiswa. Tim pegabdian menganalisis biaya yang dikeluarkan sehingga masyarakat mengetahui harga pokok penjualan produk. Pada kegiatan ini peserta telah disepakati merk dagang produk dengan mengangkat nama desa "Gondang”. Selanjutnya mahasiswa membuat desain label produk lalu mencetaknya.
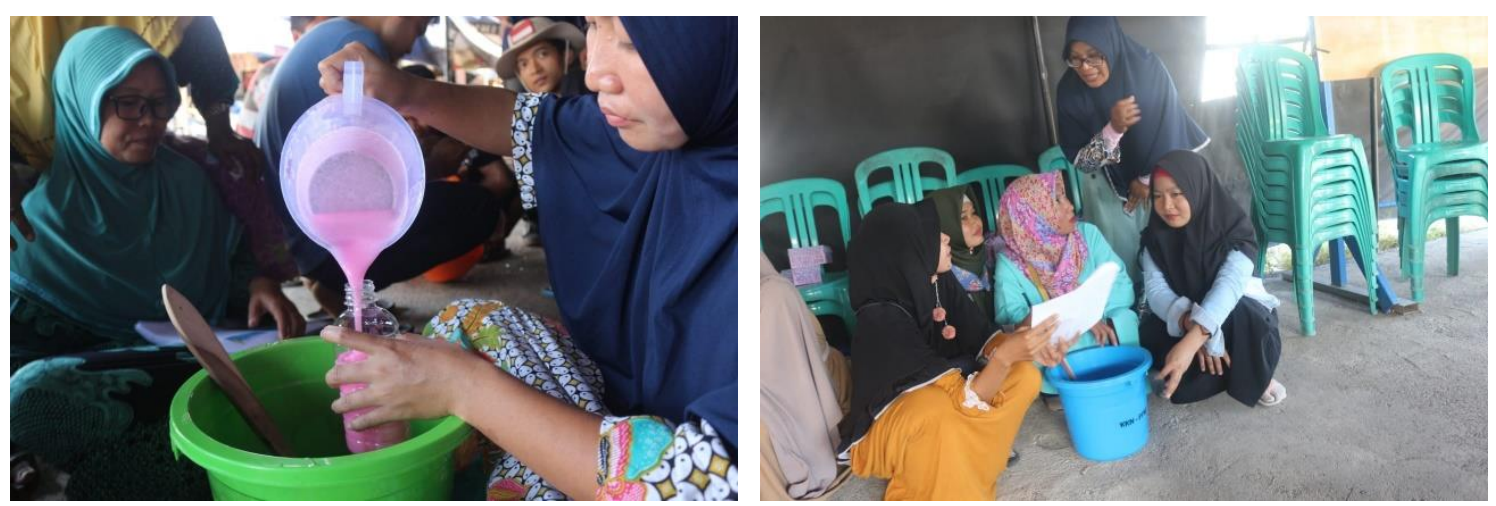

Gambar 3. Pelatihan Pembuatan Deterjen Cair, Sabun Cuci Piring, Softener, dan Softrika

5. Produksi

Tahap selanjutnya adalah produksi. Rencana awalnya adalah pada pekan ini dilakukan proses produksi dengan jumlah banyak untuk dipasarkan tetapi masyarakat meminta dilatih kembali karena pelatihan satu kali saja tidak cukup bagi mereka. Maka tahap ini lebih ditekankan pada pelatihan yang lebih intensif. Mahasiswa dan masyarakat yang bergabung dalam kelompok usaha berkoordinasi membuat jadwal pelatihan di masingmasing dusun. Peserta pelatihan yang hadir justru lebih banyak dibandingkan pelatihan awal. Akan tetapi, dua dusun tidak terlibat pada tahap ini karena kurang koordinasi antara kepala dusun dan warganya, yaitu dusun lekok tenggara dan dusun karang amor. Sedangkan sembilan dusun lainnya sangat antusias mengikuti pelatihan. Jumlah peserta dari sembilan dusun tersebut mencapai 93 orang. Pelatihan di masing-masing dusun terbagi menjadi dua sesi, pada pekan ketiga dan keempat. Proses produksi sesi pertama masih menggunakan alat manual seperti ember dan pengaduk. Pada sesi kedua, produksi dilakukan menggunakan mesin pengaduk. Produk yang dibuat pada tahap ini tetap dijual oleh masyarakat langsung. 

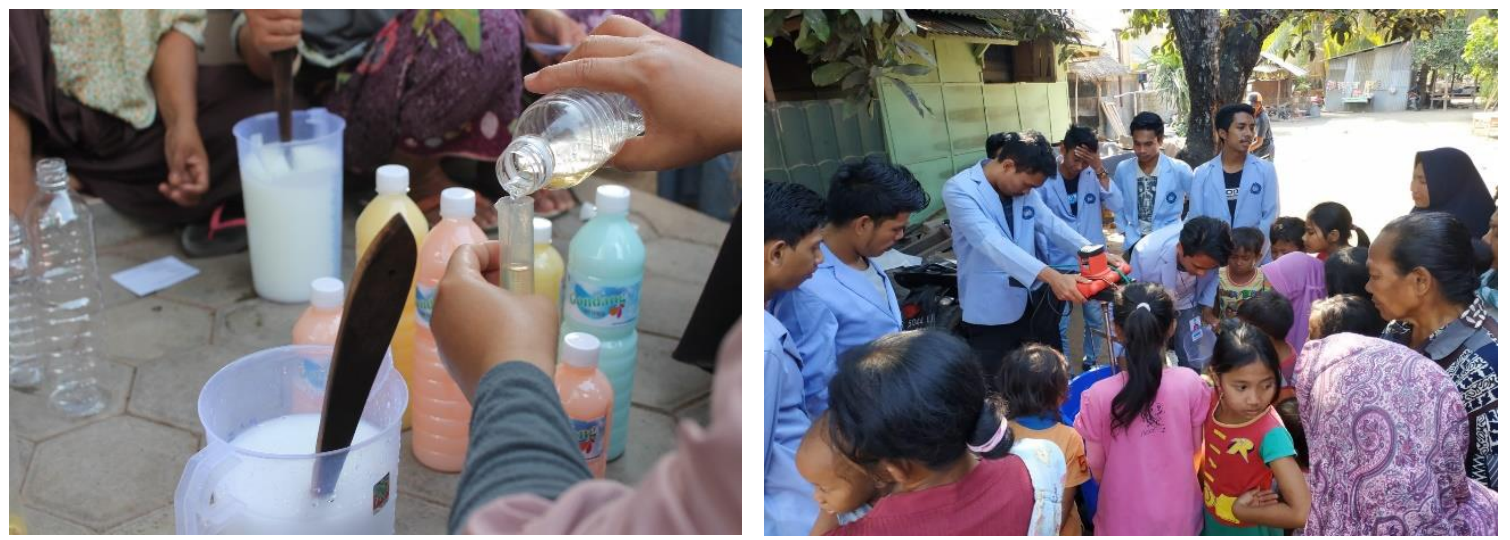

Gambar 4. Proses Produksi Deterjen Cair, Sabun Cuci Piring, Softener, dan Softrika

6. Marketing review

Tahap terakhir dari kegiatan ini adalah evaluasi atau marketing review. Evaluasi dilakukan sebanyak dua kali diakhir pekan ketiga dan keempat karena keterbatasan waktu. Tim pengabdian dibantu oleh mahasiswa mengumpulkan data berapa jumlah produk yang dibuat, berapa jumlah produk yang terjual, bagaimana usaha mereka menjual produk, serta kesulitan yang dihadapi saat membuat dan menjual produk.

Pada sesi pertama di pekan ketiga dihasilkan masing-masing produk sebanyak $45 \mathrm{~L}$. Produk yang terjual sebanyak 113,5 L dari jumlah keseluruhan $180 \mathrm{~L}$. produk yang paling banyak terjual adalah deterjen. Masyarakat menjual produk tersebut di rumah, di sekolah, serta dititipkan di warung dan laundry. Pada sesi kedua pekan keempat, berhasil diproduksi sebanyak 225 L untuk masing-masing produk. Lima kali lipat dari jumlah sebelumnya. Setelah dipasarkan beberapa hari, produk yang terjual sebanyak 312,5 L dari jumlah keseluruhan 900 L. Deterjen dan sabun piring menjadi produk yang paling laris. Hasil penjualan disimpan oleh masing-masing kelompok usaha dan digunakan sebagai modal produksi selanjutnya. Alat dan bahan yang tersisa juga dibagikan kepada masing-masing kelompok usaha sebagai tambahan modal.

Penjualan produk mengalami peningkatan jumlah berdasarkan evaluasi pertama dan kedua. Hal ini karena masyarakat sekitar mulai mengenal produk yang dibuat oleh masyarakat kelompok usaha setiap dusun. Masyarakat kelompok usaha juga lebih bersemangat melakukan promosi. Jumlah produksi tidak sebanyak yang direncanakan karena produk akan dilaunching secara resmi sebagai produk unggulan Desa Gondang di akhir kegiatan KKN PPM. Produk tersebut nantinya akan dipasarkan melalui BUMDes yang dikelola oleh pemerintah Desa Gondang. Hal ini merupakan bentuk dukungan dari pemerintah desa agar usaha ini berkesinambungan.

\section{KESIMPULAN}

Masyarakat Desa Gondang telah mendapatkan pelatihan pembuatan deterjen cair, sabun cuci piring, softener, dan softrika disertai strategi penjualan. Penjualan produk mengalami peningkatan jumlah berdasarkan evaluasi pertama dan kedua. Pendapatan masyarakat pun meningkat. Produk yang dihasilkan telah resmi dilaunching sebagai produk unggulan Desa Gondang. Tim pengabdian dan mahasiswa telah berhasil melaksanakan pemberdayaan masyarakat melalui chemistry entrepreneurship.

\section{SARAN}


Tim pengabdian menyarankan agar masyarakat kelompok usaha memanfaatkan peluang usaha dari produk yang telah dilatih demi meningkatkan kesejahteraan keluarga. Pemerintah desa juga sangat mendukung dan menyediakan wadah untuk memasarkan produk yakni melalui BUMDes.

\section{UCAPAN TERIMA KASIH}

Tim pengabdian mengucapkan terimakasih kepada Kementrian Riset, Teknologi, dan Pendidikan Tinggi melalui Direktorat Riset dan Pengabdian Masyarakat yang telah mendanai kegiatan ini dan kepada Pemerintah Desa Gondang yang telah mendukung penuh kegiatan ini.

\section{DAFTAR PUSTAKA}

Artiani, L. E. (2011). Dampak Ekonomi Makro Bencana: Interaksi Bencana Dan Pembangunan Ekonomi Nasional. Seminar Nasional Informatika. Yogyakarta.

Cavallo, Eduardo, \& Noy, I. (2011). Natural Disasters and the Economy: A Survey. International Review of Environmental and Resource Economics, 5(1), 63-102.

Fillah, A. S., Ishartono, \& Fedryansyah, M. (2010). Program Penanggulangan Bencana Oleh Disaster Management Center (DMC) Dompet Dhuafa . Prosiding KS: Riset \& PKM . Jakarta.

Oyeku, O. M., Oduyoye, O. O., Elemo, G. N., Akindoju, A. F., Karimu, F. A., \& Unuigbe, K. O. (2015). Chemistry Entrepreneurship for Small and Medium Enterprises Development: A Panacea for Job and Wealth Creation. Industrial Engineering Letters, 5(4), 1-10.

Sutarno. (2018). Akibat Gempa Lombok, Ekonomi NTB Diperkirakan Melambat. diakses tanggal 30 Agustus 2018: http://finansial.bisnis.com/read/20180831/9/833877/akibatgempa-lombok-ekonomi-ntb-diperkirakan-melambat.

Utara, B. K. (2017). Kecamatan Gangga dalam Angka 2017. Tanjung: BPS. 